ҚАЗАҚСТАН РЕСПУБЛИКАСЫ

ҰЛТТЫҚ ҒЫЛЫМ АКАДЕМИЯСЫНЫН

АБАЙ АТЫНДАҒЫ ҚАЗАҚ ҰЛТТЫҚ

ПЕДАГОГИКАЛЫҚ УНИВЕРСИТЕТІНІҢ

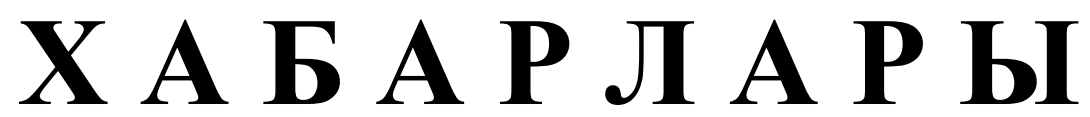

\section{ИЗВЕСТИЯ}

НАЦИОНАЛЬНОЙ АКАДЕМИИ НАУК РЕСПУБЛИКИ КАЗАХСТАН

КАЗАХСКИЙ НАЦИОНАЛЬНЫЙ

ПЕДАГОГИЧЕСКИЙ УНИВЕРСИТЕТ ИМ. АБАЯ

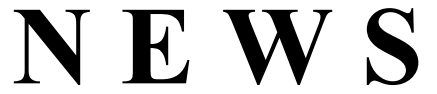

OF THE NATIONAL ACADEMY OF SCIENCES OF THE REPUBLIC OF KAZAKHSTAN

ABAY KAZAKH NATIONAL PEDAGOGICAL UNIVERSITY

ҚОҒАМДЫҚ ЖӘНЕ ГУМАНИТАРЛЫҚ ҒЫЛЫМДАР СЕРИЯСЫ

СЕРИЯ ОБЩЕСТВЕННЫХ И ГУМАНИТАРНЫХ НАУК

SERIES OF SOCIAL AND HUMAN SCIENCES

\author{
6 (322) \\ ҚАРАША - ЖЕЛТОҚСАН 2018 ж. \\ НОЯБРЬ - ДЕКАБРЬ 2018 Г. \\ NOVEMBER - DECEMBER 2018 \\ ИЗДАЕТСЯ С ЯНВАРЯ 1962 ГОДА \\ PUBLISHED SINCE JANUARY 1962 \\ ЖЫЛЫНА 6 РЕТ ШЫҒАДЫ \\ ВЫХОДИТ 6 РАЗ В ГОД \\ PUBLISHED 6 TIMES A YEAR
}

1962 ЖЫЛДЫҢ ҚАНТАР АЙЫНАН ШЫҒА БАСТАҒАН 
Ба с ре дактор

ҚР ҰҒА кұрметті мүшесі

Балықбаев Т.O.

Р е д а ц и я а лқ а сы:

экон. ғ. докторы, проф., ҚР ҰҒА академигі Баймұратов У.Б.; тарих ғ. докторы, проф., ҚР ҰҒА академигі Байпақов К.М.; филос. ғ.докторы, проф., ҚР ҰҒА академигі Есім Г.Е.; фил. ғ. докторы,, проф., ҚР ҰҒА академигі Қирабаев С.С.; эк. ғ. докторы, проф., ҚР ҰҒА академигі Кошанов А.К.; эк.ғ. докторы, проф., ҚР ҰҒА академигі Нәрібаев К.Н. (бас редактордың орынбасары); филос. ғ.докторы, проф., ҚР ҰҒА академигі Нысанбаев А.Н.; заң ғ. докторы, проф., ҚР ҰҒА академигі Сәбікенов С.Н.; заң ғ. докторы, проф., ҚР ҰҒА академигі Сүлейменов М.К.; эк. ғ. докторы, проф., ҚР ҰҒА академигі Сатыбалдин С.С.; тарих ғ. докторы, проф., ҚР ҰҒА академик Әбжанов Х.М.; тарих ғ. докторы, проф., ҚР ҰҒА корр. мүшесі Әбусеитова М.Х.; тарих ғ. докторы, проф., ҚР ҰҒА академик Байтанаев Б.А.; филол. ғ. докторы, проф., ҚР ҰҒА корр. мүшесі Жақып Б.А.; фил. ғ. докторы, проф., академик НАН РК Қалижанов У.К.; филол. ғ. докторы, проф., ҚР ҰҒА академик Қамзабекұлы Д.; тарих ғ. докторы, проф., ҚР ҰҒА академик Қожамжарова Д.П.; тарих ғ. докторы, проф., ҚР ҰҒА академик Койгелдиев М.К.; фил. ғ. докторы, проф., ҚР ҰҒА корр. мүшесі Кұрманбайұлы Ш.; тарих ғ. докторы, проф., ҚР ҰҒА корр. мүшесі Таймағанбетов Ж.К.; социол. ғ. докторы, проф., ҚР ҰҒА корр. мүшесі Шәукенова 3.К.; фил. ғ. докторы, проф., КР ҰҒА корр. мүшесі Дербісәлі А.; саяси. ғ. докторы, проф., Бижанов А.К., тарих ғ. докторы, проф., Кабульдинов 3.Е.; фил. ғ. докторы, проф., ҚР ҰҒА корр мүшесі Қажыбек Е.3.

\section{Р едакция ке н е с i:}

Молдова Республикасының ҰҒА академигі Белостечник Г. (Молдова); Әзірбайжан ҰҒА академигі Велиханлы Н. (Азербайджан); Тәжікстан ҰҒА академигі Назаров Т.Н. (Тәжікстан); Молдова Республикасының ҰҒА академигі Рошка А. (Молдова); Молдова Республикасының ҰҒА академигі Руснак Г. (Молдова); Әзірбайжан ҰҒА корр. мүшесі Мурадов Ш. (Әзірбайжан); Әзірбайжан ҰҒА корр. мүшесі Сафарова 3. (Әзірбайжан); э. ғ. д., проф. Василенко В.Н. (Украина); заң ғ. докт., проф. Устименко В.А. (Украина)

«Қазақстан Республикасы Ұлттық ғылым академиясының Хабарлары. Қоғамдық және гуманитарлық ғылымдар сериясы». ISSN 2224-5294

Меншіктенуші: «Қазақстан Республикасының Ұлттық ғылым академиясы» РҚБ (Алматы қ.)

Қазақстан республикасының Мәдениет пен ақпарат министрлігінің Ақпарат және мұрағат комитетінде 30.04.2010 ж. берілген № 10894-Ж мерзімдік басылым тіркеуіне қойылу туралы куәлік

Мерзімділігі: жылына 6 рет.

Тиражы: 500 дана.

Редакцияның мекенжайы: 050010, Алматы қ., Шевченко көш., 28, 219 бөл., 220, тел.: 272-13-19, 272-13-18, http://nauka-nanrk.kz. social-human.kz

(C) Қазақстан Республикасының Ұлттық ғылым академиясы, 2018

Типографияның мекенжайы: «Аруна» ЖК, Алматы қ., Муратбаева көш., 75. 
Главный редактор

Почетный член НАН РК

T.O. Балыкбаев

Р е дак ци онн а я коллег и я:

докт. экон. Н., проф., академик НАН РК У.Б. Баймуратов; докт. ист. н., проф., академик НАН РК К.М. Байпаков; докт. филос. Н., проф., академик НАН РК Г.Е. Есим; докт. фил. Н., проф., академик НАН РК С.С. Кирабаев; докт. экон. Н., проф., академик НАН РК А.К. Кошанов; докт. экон. Н., проф., академик НАН РК К.Н. Нарибаев (заместитель главного редактора); докт. филос. н., проф., академик НАН РК А.Н. Нысанбаев; докт. юр. Н., проф., академик НАН РК С.Н. Сабикенов; докт. юр. н., проф., академик НАН РК М.К. Сулейменов; докт. экон. Н., проф., академик НАН РК С.С. Сатубалдин; докт. ист. н., проф., академик НАН РК Х.М. Абжанов; докт. ист. н., проф., чл.-корр. НАН РК М.Х. Абусеитова; докт. ист. н., проф., академик НАН РК Б.А. Байтанаев; докт. фил. н., проф., чл.-корр. НАН РК Б.А. Жакып; докт. фиолол. н., проф., академик НАН РК У.К. Калижанов; докт. фил. н., проф., академик НАН РК Д. Камзабекулы; докт. ист. н., проф., академик НАН РК Д.П. Кожамжарова; докт. ист. н., проф., академик НАН РК М.К. Койгельдиев; докт. филол. н., проф., чл.-корр. НАН РК Ш. Курманбайулы; докт. ист. н., проф., чл.корр. НАН РК Ж.К. Таймаганбетов; докт. социол. н., проф., чл.-корр. НАН РК З.К. Шаукенова; д. филол. н., проф., чл.-корр. НАН РК А. Дербисали; доктор политических наук, проф., Бижанов А.К.; доктор ист. наук, проф., Кабульдинов 3.Е.; доктор филол. н., проф., член-корр. НАН РК Қажыбек Е.3.

Р е дак ци онны й с ов ет

академик НАН Республики Молдова Г. Белостечник (Молдова); академик НАН Азербайджанской Республики Н. Велиханлы (Азербайджан); академик НАН Республики Таджикистан Т.Н. Назаров (Таджикистан); академик НАН Республики Молдова А. Рошка (Молдова); академик НАН Республики Молдова Г. Руснак (Молдова); чл.-корр. НАН Азербайджанской Республики Ш. Мурадов (Азербайджан), член-корр. НАН Азербайджанской Республики 3.Сафарова (Азербайджан); д. э. н., проф. В.Н. Василенко (Украина); д.ю.н., проф. В.А. Устименко (Украина)

Известия Национальной академии наук Республики Казахстан. Серия общественных и гуманитарных наук. ISSN 2224-5294

Собственник: РОО «Национальная академия наук Республики Казахстан» (г. Алматы)

Свидетельство о постановке на учет периодического печатного издания в Комитете информации и архивов

Министерства культуры и информации Республики Казахстан № 10894-Ж, выданное 30.04.2010 г.

Периодичность 6 раз в год

Тираж: 500 экземпляров

Адрес редакции: 050010, г. Алматы, ул. Шевченко, 28, ком. 219, 220, тел. 272-13-19, 272-13-18, www:nauka-nanrk.kz / social-human.kz

(C) Национальная академия наук Республики Казахстан, 2018 г.

Адрес типографии: ИП «Аруна», г. Алматы, ул. Муратбаева, 75

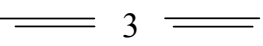


Chief Editor

\section{Honorary member of NAS RK \\ Balykbayev T.O}

Editorial board:

Doctor of economics, prof, academician of NAS RK Baimuratov U.B.; doctor of history, prof, academician of NAS RK Baipakov K.M.; doctor of philosophy, prof, academician of NAS RK Esim G.E.; doctor of philology, prof, academician of NAS RK Kirabayev S.S.; doctor of economics, prof, academician of NAS RK Koshanov A.K.; doctor of economics, prof, academician of NAS RK Naribayev K.N. (deputy editor-in-chief); doctor of philosophy, prof, academician of NAS RK Nyssanbayev A.N.; doctor of law, prof, academician of NAS RK Sabikenov S.N.; doctor of law, prof, academician of NAS RK Suleymenov M.K.; doctor of economy, prof, academician of NAS RK Satybaldin S.S.; doctor of history, prof, academician of NAS RK Abzhanov H.M; doctor of history, prof, corresponding member of NAS RK Abuseitova M.H.; doctor of history, prof, academician of NAS RK Baitanaev B.A.; doctor of philology, prof, corresponding member of NAS RK Zhakyp B.A.; doctor of philology, prof, academician of NAS RK Kalizhanov U.K.; doctor of philology, prof, academician of NAS RK Hamzabekuly D.; doctor of history, prof, academician of NAS RK Kozhamzharova D.P.; doctor of history, prof, academician of NAS RK Koigeldiev M.K.; doctor of philology, prof, corresponding member of NAS RK Kurmanbaiuly Sh.; doctor of history, prof, academician of NAS RK Taimaganbetov J.K.; doctor of sociology, prof, corresponding member of NAS RK Shaukenova Z.K.; doctor of philology, prof, corresponding member of NAS RK Derbisali A.; doctor of political science, prof Bizhanov A.K; doctor of History, prof Kabuldinov Z.E.; doctor of philology, prof, corresponding member of NAS RK Kazhybek E.Z.

\section{Editorial staff:}

Academician NAS Republic of Moldova Belostechnik.G (Moldova); Academician NAS Republic of Azerbaijan Velikhanli N. (Azerbaijan); Academician NAS Republic of Tajikistan Nazarov T.N. (Tajikistan); Academician NAS Republic of Moldova Roshka A. (Moldova) Academician NAS Republic of Moldova Rusnak G. (Moldova); Corresponding member of the NAS Republic of Azerbaijan Muradov Sh. (Azerbaijan); Corresponding member of the NAS Republic of Azerbaijan Safarova Z. (Azerbaijan); Associate professor of Economics Vasilenko V.N. (Ukraine), Associate professor of Law Ustimenko V.A. (Ukraine)

News of the National Academy of Sciences of the Republic of Kazakhstan. Series of Social and Humanities. ISSN 2224-5294

Owner: RPA "National Academy of Sciences of the Republic of Kazakhstan" (Almaty)

The certificate of registration of a periodic printed publication in the Committee of information and archives of the Ministry of culture and information of the Republic of Kazakhstan N 10894-Ж, issued 30.04.2010

Periodicity: 6 times a year

Circulation: 500 copies

Editorial address: 28, Shevchenko str., of. 219, 220, Almaty, 050010, tel. 272-13-19, 272-13-18, www:nauka-nanrk.kz / social-human.kz

(C) National Academy of Sciences of the Republic of Kazakhstan, 2018

Address of printing house: ST "Aruna", 75, Muratbayev str, Almaty 
N E W S

OF THE NATIONAL ACADEMY OF SCIENCES OF THE REPUBLIC OF KAZAKHSTAN

SERIES OF SOCIAL AND HUMAN SCIENCES

ISSN 2224-5294

https://doi.org/10.32014/2018.2224-5294.33

Volume 6, Number 322 (2018), 33 - 41

\author{
Sh.G. Jumadilova ${ }^{1}$, B.Zh. Atabay ${ }^{2}$ \\ ${ }^{1}$ International Information Technology University, Almaty, Kazakhstan; \\ ${ }^{2}$ Almaty University of Power Engineering and Communication, Almaty, Kazakhstan \\ sh.jumadilova@iitu.kz, begeibek@gmail.com
}

\title{
DYNAMICS OF THE POPULATION SAVINGS IN KAZAKHSTAN
}

\begin{abstract}
The paper investigates dynamics of population savings and factors affecting it. Dynamics of population savings were measured by individuals' savings. As potential factors average salary, exchange rate and interest rate for both tenge deposits and deposits in foreign currency were taken. With significant factors identified, respective regression model was developed. It was justified the relationship between total individuals' deposits and average trimmed salary, total individuals' deposits and currency rate. Structural analysis and analysis of dynamics were used to compare the changes in components of total deposits. The results show a positive trend in individuals' deposits in tenge rather than in USD. For research purpose statistical data for 2010-2017 years was used. Moreover, effect of entering Kazakhstan Deposit Insurance Fund on the size of deposits was studied. Among research results unexpected one was that interest rate for deposits and deposits size are not interrelated. Deposits are considered as one of the sources for investments into economy. Therefore, some predictions on deposit size for coming years are done. Conclusion summarizes main research results.
\end{abstract} Fund.

Keywords: population savings, individuals' savings, deposits, deposit insurance, Kazakhstan Deposit Insurance

Introduction. The issue of increasing population's savings is one of the significant research problems. There are several studies made by different scientists. Some recent ones among them are $[1,2]$. This paper differs from them by investigating factors affecting population's savings via regression analysis.

There are many researches on effects of deposit insurance, mainly investigating whether it promote banking industry stability or moral hazard $[3,4]$

Jameaba [5] analyzed the effects of the establishment of the Indonesia Deposit Insurance Corporation (IDIC) and found a shift in the composition of bank deposits from time deposits and demand deposits to savings deposits. Since Kazakhstan entered KDIF as well, paper raises a question about effects of it on deposits.

Concerning the case of Kazakhstan, in recent years, especially since global financial crisis, when almost every country's economy collapsed, the fact that deposit insurance plays a crucial role in maintaining financial stability and promoting safe banking system has been recognized.

Since the early 90's more than 113 countries have adopted an explicit deposit insurance system [6]. The Republic of Kazakhstan was not an exception and KDIF (Kazakhstan Deposit Insurance Fund) was established in 15 November, 1999 back then called "Incorporation of ZAO "Kazakhstan Individuals Deposit Guarantee (Insurance) Fund".

Types of bank deposit accounts are current deposit accounts, savings account, and time deposit accounts. Deposit Insurance is protection provided usually by a government agency to depositors against risk of loss arising from failure of a bank or other depository institution. Deposit insurance is mandatory in Kazakhstan, and pays claims from a pool of funds to which every depository institution regularly contributes. However, it covers only a fixed maximum amount per account holder.

Kazakhstan Deposit Insurance Fund (KDIF) was established with a view to building confidence in the Kazakhstani banking system as a framework of protection of bank deposits of general public. This issue became critical for the Republic of Kazakhstan after the financial crisis of 1998 burst in Russian Federation [7]. KDIF is a non-profit organization. National (Central) Bank of the Republic of Kazakhstan is the founding institution and the sole shareholder of KDIF.

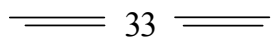


The basic objective of deposit insurance system is to maintain stability of financial system, including via maintaining public confidence in Kazakhstani banking sector via establishing the framework to reimburse bank depositors in the event of a Deposit Insurance System (DIS) member bank failure.

During 18 years of work, several changes happened in rules of KDIF, which consequently affected the dynamics of deposits in banks of Kazakhstan. The main purpose of this paper is to explain the work of deposit insurance system in the Republic of Kazakhstan, analyze the changes in the number of savings in frequent years using the models to determine the factors which affect savings decisions of individuals and non-banking legal entities and come to the suggestive conclusions.

Methodology and data. In this paper, as population's savings, deposits are taken for following reasons: no access to statistics of investments volume; existence of non-registered savings (for example, people tend to keep their savings under bed, it was common back then and still exists, especially amongst elder generation); big range of possible savings placements which does not allow to cover them all.

Research results are derived using the software MS Excel. To find the relationships between deposits' size and affecting factors such as salary, interest rate and exchange rate scatter diagrams were plotted and further multiple regression analysis was implemented with construction of respective regression model. Comparative analysis between indicators for 2010-2017 was done. Since the main theme is dynamics of individuals' deposits, as for dependent variable total volume of individuals' deposits in measurement of million tenge was taken for each segment of analysis. As independent variables were taken average trimmed salary of individuals' (in tenge), average policy of exchange rate (dollar to tenge), annual interest rate (in \%) for deposits. To find the tendency of changes over time linear, exponential and polynomial lines were used as a tool for visual interpretation. Structural analysis was used to compare the changes in components of total deposits. For analysis 2010-2017 years' statistics was used. As for KDIF and deposits' relationships analysis, dummy variables as an alternative for existence/non-existence were taken.

Research Results. According to the Law of the Republic of Kazakhstan "Regarding amendments and additions to several legislative acts of Kazakhstan on strengthening protection of property rights, providing guarantees for protecting contractual obligations and toughening liability for their violation", the deposit insurance coverage limit applied to deposits in national currency increased from 5 million to 10 million tenge. The coverage limit for deposits in foreign currency was retained on the same level of 5 million tenge.

The deposit insurance coverage limit extended to any bank deposit or bank account of a single depositor in any single bank shall comprise:

For deposits and bank accounts in tenge: 10 million tenge;

For deposits and bank accounts in any foreign currency: 5 million tenge (in equivalent, at the exchange rate as of the date of enactment of the court resolution governing forced liquidation of deposit insurance system member bank).

Table 1 - Structure of total individuals deposits

\begin{tabular}{|c|c|c|l|l|l|l|l|}
\hline & \multicolumn{6}{|c|}{ Individuals Deposits, end of period, mln.KZT } \\
\cline { 2 - 8 } & & \multicolumn{2}{|c|}{$\begin{array}{c}\text { including individuals } \\
\text { demand deposits and } \\
\text { current accounts }\end{array}$} & \multicolumn{2}{|c|}{$\begin{array}{c}\text { including individuals } \\
\text { deposits }\end{array}$} & \multicolumn{2}{c|}{$\begin{array}{c}\text { including individuals time } \\
\text { deposits }\end{array}$} \\
\hline Year & Total & $\begin{array}{c}\text { national } \\
\text { currency } \\
\text { (DDCA) }\end{array}$ & $\begin{array}{c}\text { foreign } \\
\text { currency } \\
\text { (DDCA) }\end{array}$ & $\begin{array}{c}\text { national } \\
\text { currency (ID) }\end{array}$ & $\begin{array}{c}\text { foreign } \\
\text { currency } \\
\text { (ID) }\end{array}$ & $\begin{array}{c}\text { national } \\
\text { currency } \\
\text { (ITD) }\end{array}$ & $\begin{array}{c}\text { foreign } \\
\text { currency (ITD) }\end{array}$ \\
\hline 2009 & 1717478 & 163369 & 67760 & 2332 & 1512 & 542825 & 939681 \\
\hline 2010 & 2075849 & 210333 & 61885 & 3414 & 1029 & 851293 & 947896 \\
\hline 2011 & 2488131 & 262597 & 52626 & 7801 & 1114 & 1157829 & 1006163 \\
\hline 2012 & 3056481 & 332466 & 61907 & 7260 & 5533 & 1449339 & 1199978 \\
\hline 2013 & 3663105 & 378141 & 64926 & 16561 & 6041 & 1739245 & 1458190 \\
\hline 2014 & 4292262 & 384646 & 91950 & 23401 & 7857 & 1503762 & 2280645 \\
\hline 2015 & 5033513 & 345903 & 135129 & 11841 & 20135 & 1027059 & 3493446 \\
\hline 2016 & 7233730 & 433710 & 198181 & 7412 & 18735 & 1745814 & 4829878 \\
\hline 2017 & 7895994 & 536324 & 196009 & 6764 & 16111 & 2896707 & 4244077 \\
\hline
\end{tabular}

Source: [8-11] 
Two following pie-charts describe components of deposits by type visually. To distinguish changes over time, data from 2009 and 2017 are compared (Figures 1 and 2).

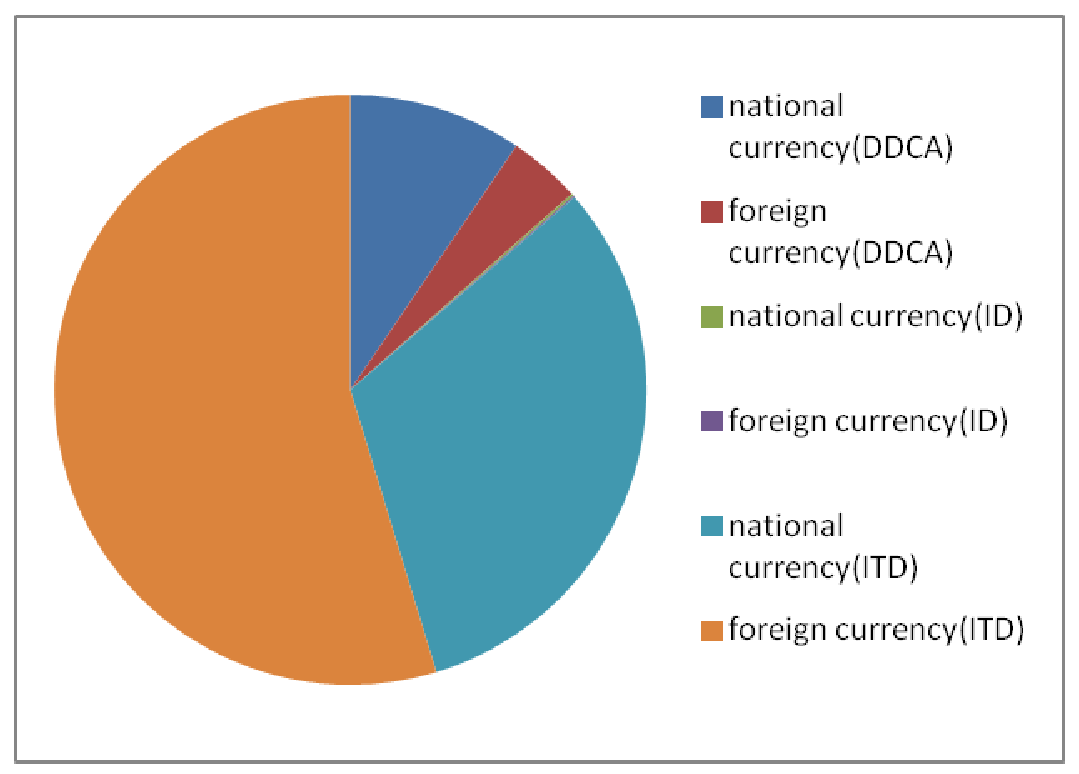

Figure 1 - Structure of deposits of individuals in 2017

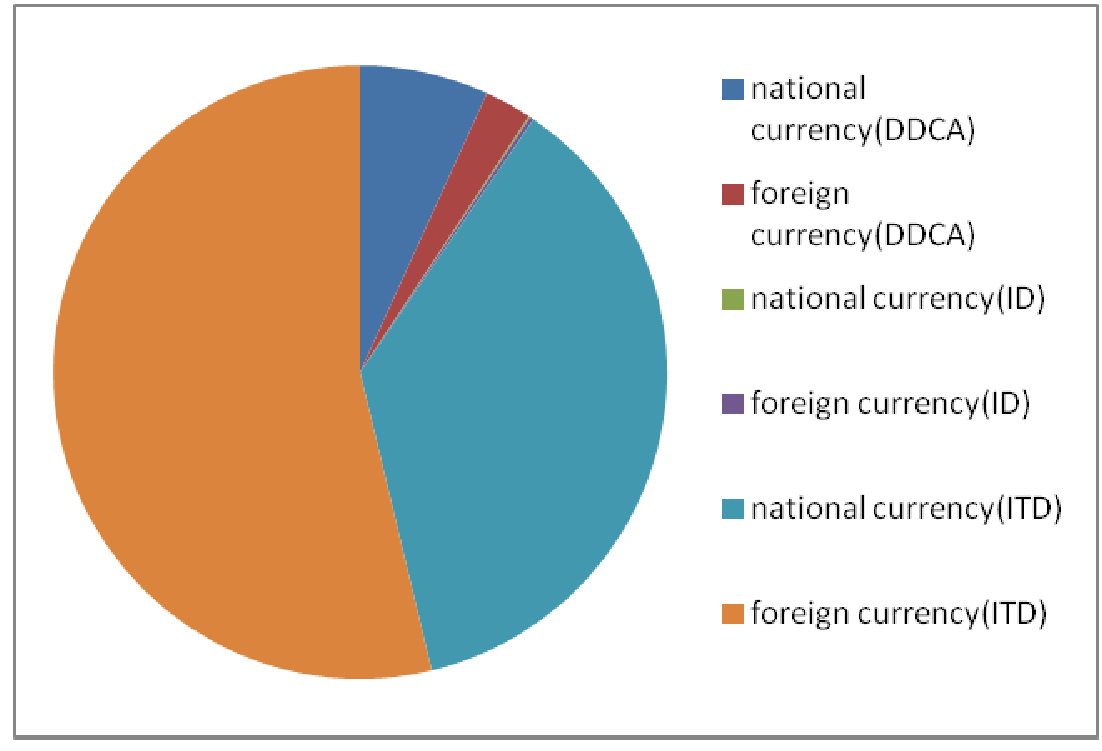

Figure 2 - Structure of deposits of individuals in 2017

From pie-chart, it can be seen that in both 2009 and 2017 individual time deposits (ITD) in both foreign and national currency took lion's share: $87 \%$ and $91 \%$ respectively. Demand deposits (DDCA) were less popular: 13\% in 2009 and 9\% in 2017 (including deposits in both currencies). Other types of individuals' deposits (ID) were least popular: $2 \%$ in 2009 and $0 \%$ in 2017. It can be concluded that time deposits are becoming more popular, replacing other deposits.

Deposits in foreign currency were more in volume rather than in national currency. In $2009,59 \%$ of deposits' size was in foreign currency, whereas $56 \%$ was an indicator for 2017 . However, it can be concluded that savings in national tenge are slowly becoming more demanded.

The following graphs illustrate overall dynamics of deposits of individuals in Kazakhstan by its type in 2009-2017 (Figure 3). 


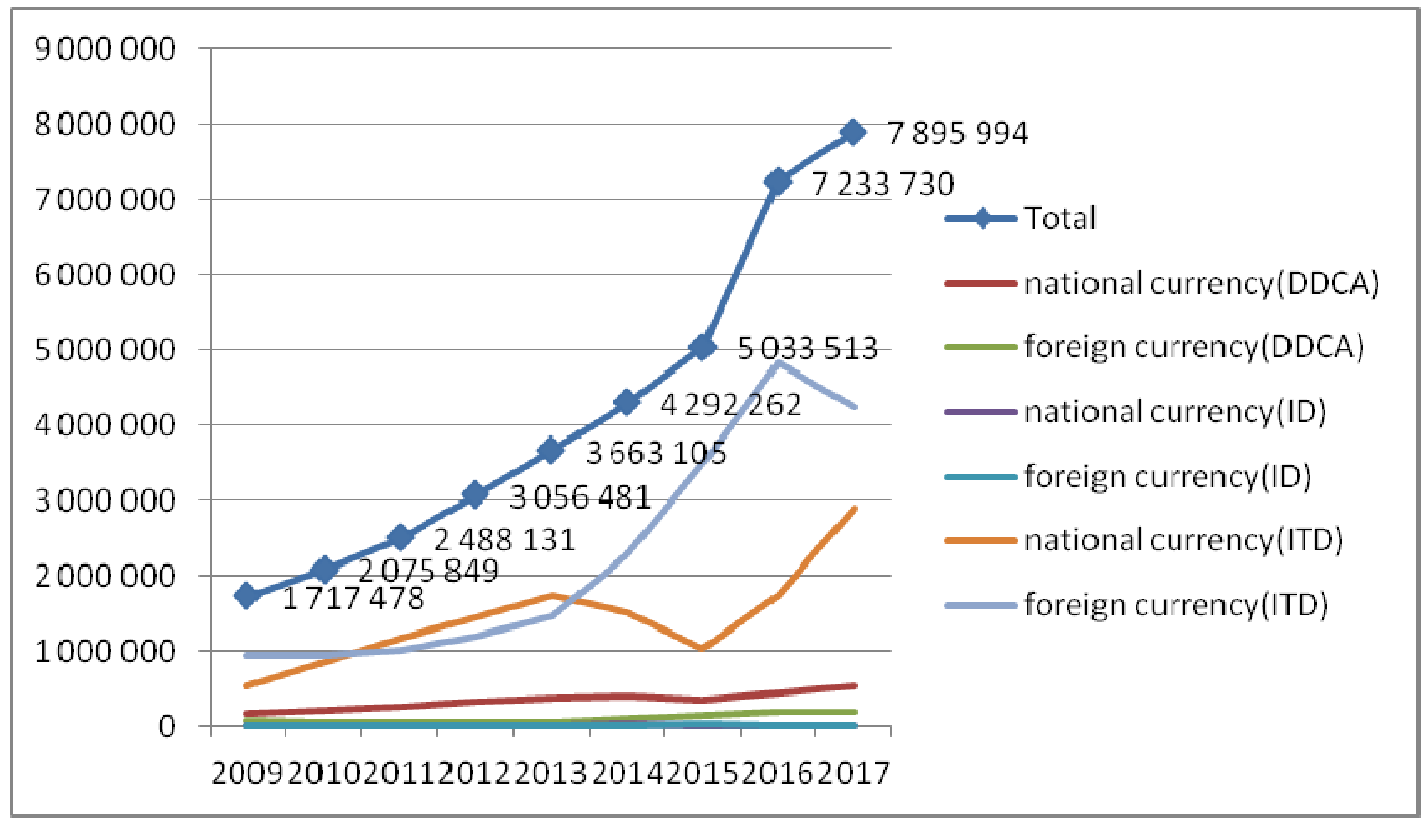

Figure 3 - Dynamics of individuals' deposits in Kazakhstan by type in 2009-2017

According to the information from the official internet resource of NBRK, as for individual's savings, there's been a continuous increase over time. The number of deposits grew moderately in a period from 2009 until 2015, varying with the difference from year to year. Sharp increase was from 2015 to 2016.

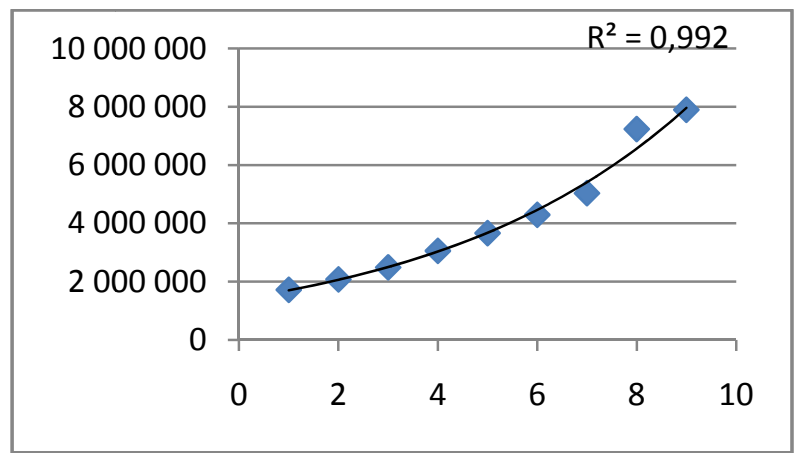

Figure 4 - Trend in dynamics of individuals' savings

As seen from Figure 4, the dynamics of individuals' savings are better explained with exponential curve rather straight line. $R^{2}$ value of 0.9927 is an evidence of good fit. Whenever $\mathrm{x}$ increases by 1 , the estimate from an exponential curve increases by the same percentage. As a result, we'll find that the estimate of deposit's growth rate is $21.32 \%$.

According to the historical tendency of growth, estimated total for 2018 is $9661434.89 \mathrm{mln}$ tenge and for 2019 is $11721288.09 \mathrm{mln}$ tenge. Overall, deposits are tended to rise from year to year. However, although exponential growth was used for deposits since in a total it tended only to grow over time, it's better to remember that exponential growth cannot last forever and further linear relationships might be better fit.

Are volume of deposits and average salary of individuals interrelated?

Major part of individual's income comes from their salary. Therefore, there is a point to say, that deposits' dynamics strongly related to average salary. As for salary indicator, we trimmed the highest and the lowest values, and then got average salary. Total individuals deposits averaged in a year and average trimmed salary are given in Table 2 . 
Table 2 - Total individuals deposits and average trimmed salary

\begin{tabular}{|c|c|c|c|}
\hline & & Total individuals deposits (mln tenge) & Average trimmed salary (tenge) \\
\hline 1 & 2010 & 2075849 & 77609.95 \\
\hline 2 & 2011 & 2488131 & 89800.54 \\
\hline 3 & 2012 & 3056481 & 101304 \\
\hline 4 & 2013 & 3663105 & 107898 \\
\hline 5 & 2014 & 4292262 & 119374 \\
\hline 6 & 2015 & 5033513 & 124138.2 \\
\hline 7 & 2016 & 7233730 & 141417.1 \\
\hline 8 & 2017 & 7895994 & 144070.6 \\
\hline
\end{tabular}

At first, let us draw a scatterplot for the data above (Figure 5).

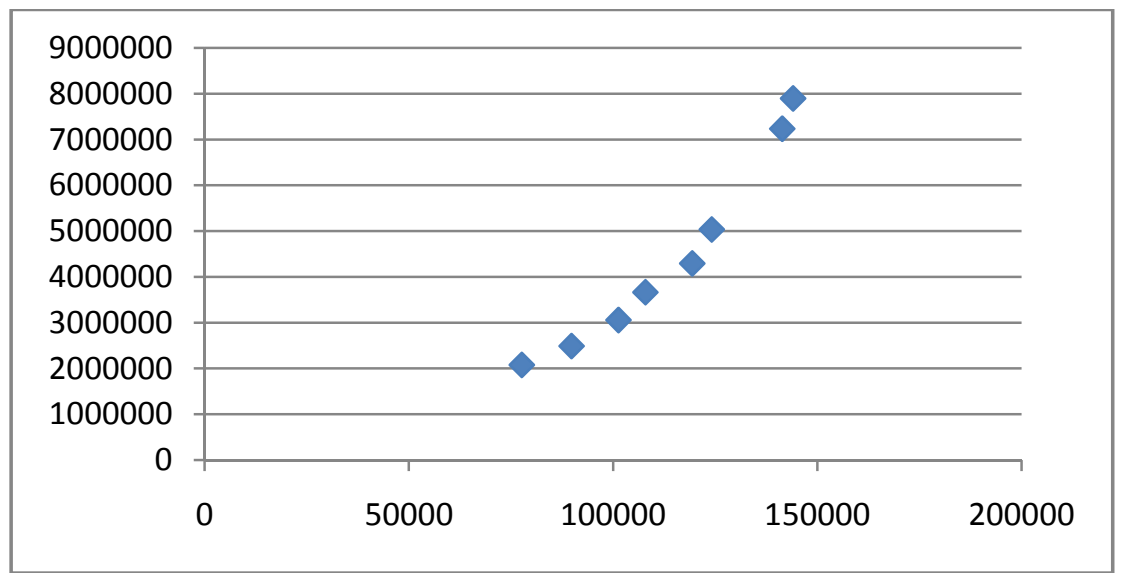

Figure 5 - Scatterplot of total individuals' deposits and average trimmed salary

From Figure 5 one can see obvious relationship between total individuals' deposits and average trimmed salary. Since total individuals' deposits shows strong dependence on average trimmed salary, let us investigate changes in salary over time. Tendency of changes in salary over time is straight line upward trend. So, we can use trend equation to predict salary in coming year.

\section{Exchange rate and deposits}

Now, let us study other factors affecting deposits in Kazakhstan. Since one of the main factors in people's decision-making is currency rate of US dollar to tenge, consider whether people tend to save more with increase in currency rate or not. Respective scatterplot is shown in Figure 6.

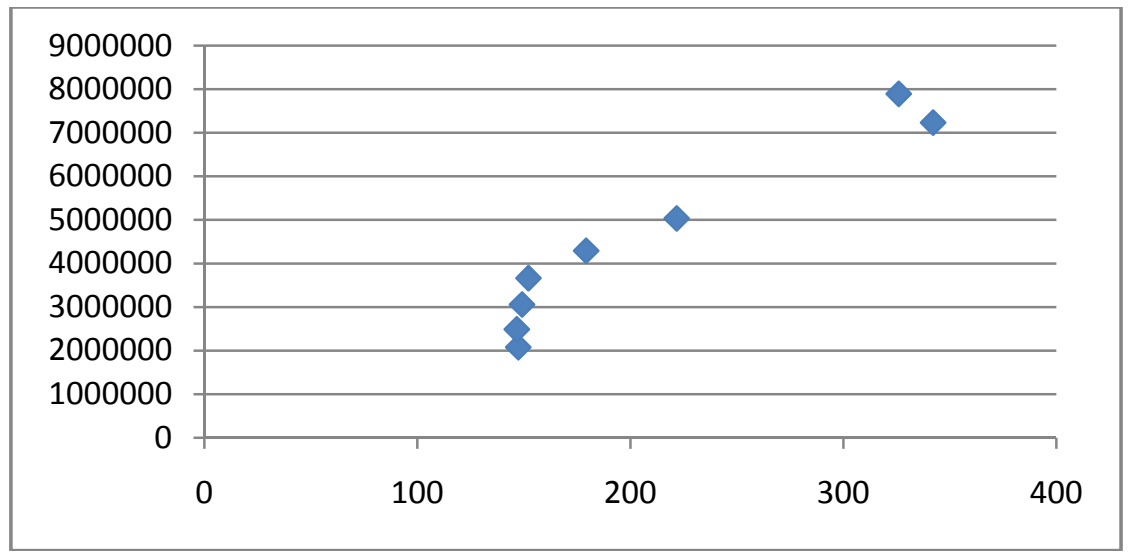

Figure 6 - Scatterplot of total average individuals' deposits and currency rate (tenge per 1 USD) 
For the prediction purpose we can determine a trend equation for currency rate. However, even historical evidences prove that there is a tendency in changes of interest rate, in a reality it is not so common, because lots of external and internal factors/events may affect exchange rate so, that it may change sharply and unexpectedly. For example, in 2015 as a result of decrease in a price of oil, tenge was released into free floating; consequently it depreciated from 179 to 222 tenge per dollar. This kind of changes cannot be precisely predicted. Thus, it is better to remember that estimations on future exchange rate sometimes might be of little use.

\section{Interest rate and deposits}

As is known, higher (lower) interest rates should provide higher (lower) demand for deposits. However, in practice, there is no enough strong relations for estimation. Since all data below was for individuals, whereas volume of deposits include both individuals and non-banking entities, it is fair to use non-banking entities' deposits now. For savings in national currency, historically situation was as follows in Table 3.

Table 3 - Deposits of non-banking legal entities and their annual interest rate

\begin{tabular}{|c|c|c|c|c|}
\hline Years & $\begin{array}{c}\text { Deposits of non-banking legal } \\
\text { entities (tenge) }\end{array}$ & $\begin{array}{c}\text { Interest rate, \% (for } \\
\text { tenge deposits) }\end{array}$ & $\begin{array}{c}\text { Deposits of non-banking } \\
\text { legal entities (in foreign } \\
\text { currency) }\end{array}$ & $\begin{array}{c}\text { Interest rate, \% (for } \\
\text { deposits in foreign } \\
\text { currency }\end{array}$ \\
\hline 2010 & 3361736 & 3.5 & 1777908 & 1.9 \\
\hline 2011 & 4079784 & 3 & 1589773 & 0.6 \\
\hline 2012 & 4318377 & 2.8 & 1618494 & 2.1 \\
\hline 2013 & 4232794 & 3 & 1959158 & 1.8 \\
\hline 2014 & 4281506 & 4.8 & 3102694 & 2.4 \\
\hline 2015 & 3871123 & 11.1 & 3935523 & 2.5 \\
\hline 2016 & 4699694 & 29.3 & 5225517 & 1.8 \\
\hline 2017 & 5538119 & 10.4 & 4330039 & \\
\hline
\end{tabular}

The next scatter diagrams show that there is no relationship neither between deposits of non-banking legal entities in tenge and annual interest rate for tenge deposits (Figure 7) nor between deposits of nonbanking legal entities in foreign currency and annual interest rate for deposits in foreign currency (Figure 8).

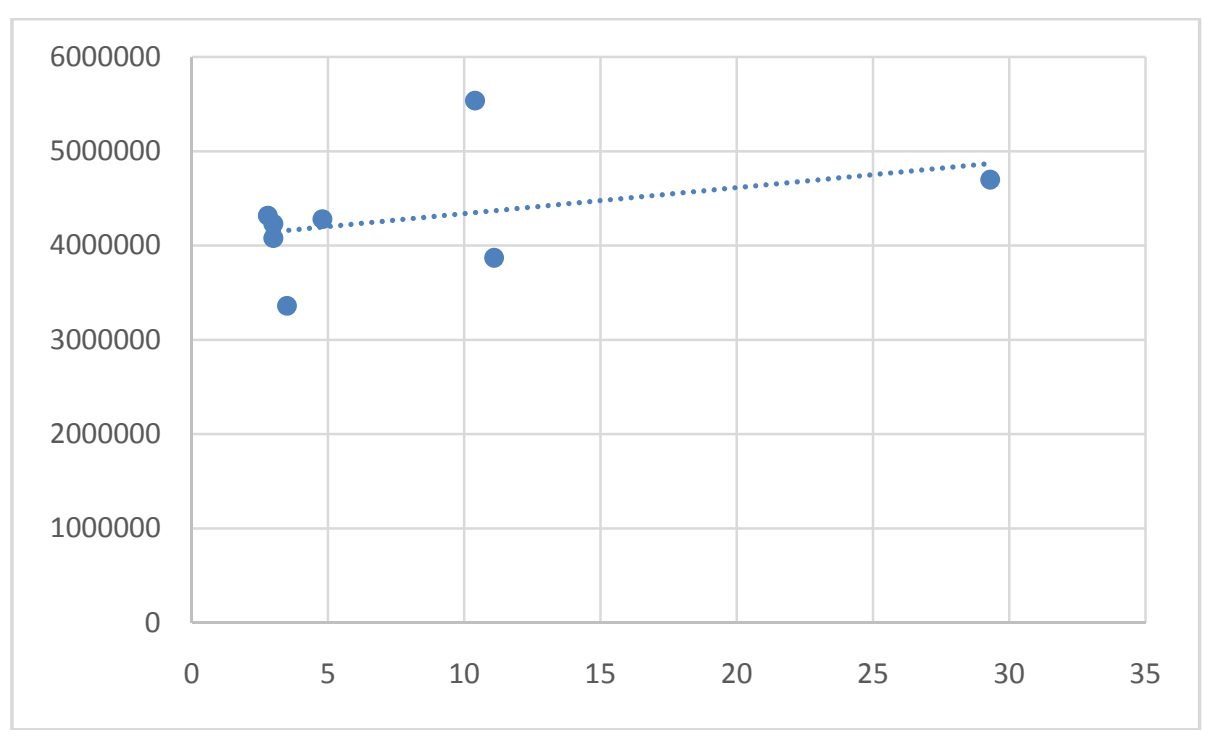

Figure 7 - Scatterplot between deposits of non-banking legal entities in tenge and Interest Rate 


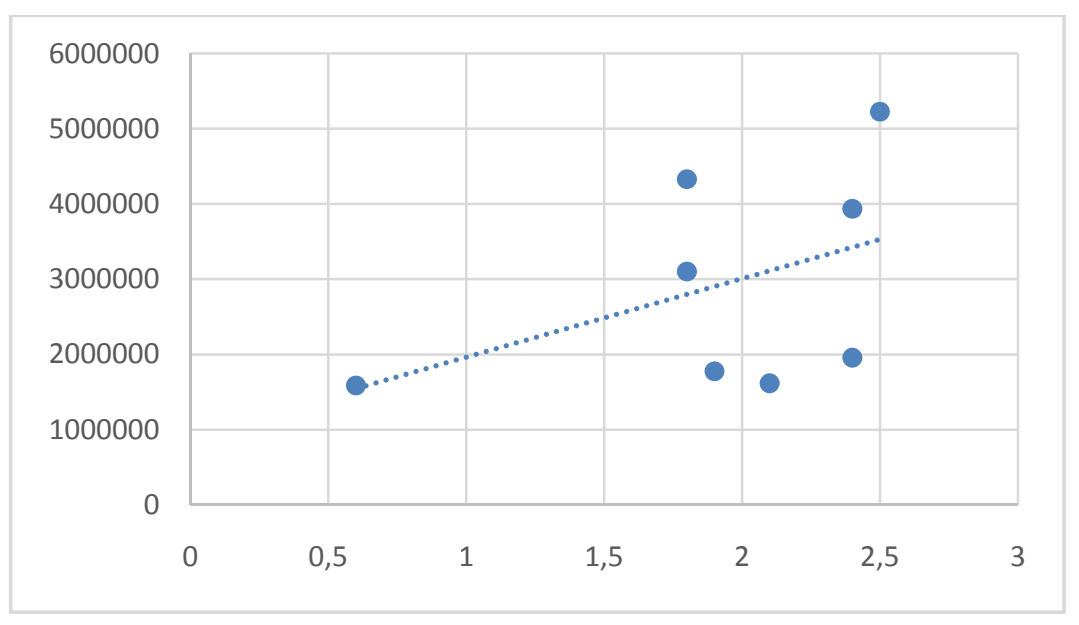

Figure 8 - Scatterplot between deposits of non-banking legal entities in foreign currency and Interest Rate

We can conclude interest rate had no effect on volume of deposits during 2010-2017.

\section{KDIF and deposits}

Since KDIF provides insurance for deposits, there is a point to say that after establishment of such service trust of nation for banks' safety increased. Compare dynamics of deposits before and after KDIF (Table 4).

Table 4 - Dynamics of individuals' deposits before and after KDIF

\begin{tabular}{|c|c|c|c|}
\hline & $\begin{array}{c}\text { KDIF } \\
\text { existence }\end{array}$ & Volume of individuals' deposits & Growth rate \\
\hline 1998 & no & 31039 & \\
\hline 1999 & no & 39701 & $27.91 \%$ \\
\hline 2000 & yes & 72128 & $81.68 \%$ \\
\hline 2001 & yes & 141810 & $96.61 \%$ \\
\hline 2002 & yes & 219836 & $55.02 \%$ \\
\hline
\end{tabular}

Since KDIF was established at the end of 1999, we've decided to define it as 'did not exist' for this year for more accurate outcome. As a result, we can notice sharp increase after KDIF establishment. Before KDIF growth was only $27.91 \%$, whereas after KDIF it was $81.68 \%, 96.61 \%, 55.02 \%$ in 2000 , 2001 and 2002 correspondingly. Overall, we can say, that volume of deposits rose once KDIF was established.

\section{Factors affecting deposits' size}

If we combine all significant factors which were identified above, multiple regression model can be developed and it is as follows:

Predicted deposits $=-3631848+47.5914 *$ (Average salary) +13035.32 (Average exchange rate)

$\mathrm{R}^{2}=0.9888$

S.E. $=268254$.

According to p-value, we can say, that both independent variables are useful (p-value for salary is 0.0037 , for exchange rate 0.0046 ).

Therefore, predicted value for volume of deposits in 2018 is $9444867 \mathrm{mln} \mathrm{kzt}$ and in 2019 is 11085 $376 \mathrm{mln} k z t$.

\section{Conclusion}

From the research one can conclude the following:

1. Time deposits have been the most popular. Deposits in foreign currency are still dominant in the market, but deposits in tenge slowly becoming stronger and demanded. 
2. Despite of market conditions, deposits' volume tend to only grow over previous 10 years with an estimate growth rate of $21.32 \%$.

3. Average salary and volume of deposits are interrelated. Growth in salaries of individuals causes willingness of individuals to save more.

4. Currency rate and volume of deposits are also interrelated. Historically, several depreciations happened in value of tenge. However, it influenced positively the growth of population's savings.

5. Establishment of KDIF definitely influenced on growth positively, increasing trust of individuals for banking system of Kazakhstan.

6. During research was found out surprisingly that interest rate of banks attracted deposits and deposits by itself are not interrelated. Changes in interest rate do not influence volume of deposits.

7. In conclusion, overall estimation for 2018 deposits based on several facts, vary from 9295211.88 to 10127057.64 , whereas for 2019 it is between 11085376 and 12417227.64 .

\section{REFERENCES}

[1] Loibl, C., L. Jones and E. Haisley. (2018) Testing Strategies to Increase Saving in Individual Development Account Programs. Journal of Economic Psychology 66:45-63. DOI: 10.1016/j.joep.2018.04.002 (in Eng).

[2] Wang, J. S. H., F. M. Ssewamala, T. B. Neilands, L. G. Bermudez, I. Garfinkel, J. Waldfogel, J. Brooks-Gunn and J. You. (2018) Effects of Financial Incentives on Saving Outcomes and Material Well-Being: Evidence from a Randomized Controlled Trial in Uganda. Journal of Policy Analysis and Management 37(3):602-+. DOI: 10.1002/pam.22065 (in Eng).

[3] Kusairi, S., N. A. Sanusi and A. G. Ismail. (2018) Dilemma of Deposit Insurance Policy in Asean Countries: Does It Promote Banking Industry Stability or Moral Hazard? Borsa Istanbul Review 18(1):33-40. DOI: 10.1016/j.bir.2017.08.006 (in Eng).

[4] Mumtaz, R. and I. A. Jadoon. (2018) Effect of Explicit Deposit Insurance Premium on the Moral Hazard of Banks' RiskTaking: Around the Globe. International Journal of Financial Engineering 5(2):24. DOI: 10.1142/s2424786318500123 (in Eng).

[5] Jameaba, M. S. (2018) Deposit Insurance and Financial Intermediation: The Case of Indonesia Deposit Insurance Corporation. Cogent Economics \& Finance 6(1):1-32. DOI: 10.1080/23322039.2018.1468231 (in Eng).

[6] IADI. International Association of Deposit Issuers. Annual report. 2015-2016. (in Eng)

[7] KDIF. Deposit Insurance System in Kazakhstan. [online access at: http://www.kdif.kz/en/sistema-garantirovaniyadepozitov-v-rk] (in Eng).

[8] National Bank of Kazakhstan. Deposits of individuals in the banks of Kazakhstan in 2009-2017. [online access at: http://www.nationalbank.kz/?docid=194\&switch=english] (in Eng)

[9] National Bank of Kazakhstan. Statistical bulletin. 2018.N3(280). http://www.nationalbank.kz/cont/Итог115.pdf (in Eng).

[10] National Bank of Kazakhstan. Statistical bulletin. $2015 . \quad$ N12(253). http://www.nationalbank.kz/cont/publish531507_31330.pdf (in Eng).

[11] National Bank of Kazakhstan.

http://www.nationalbank.kz/cont/publish658075_7844.pdf (in Eng).

Statistical bulletin. 2012. N1(206).

МРНТИ 06.73 .55

УДК 336.7

\section{Ш.Г. Джумадилова ${ }^{1}$, Б.Ж. Атабай}

${ }^{1}$ Международный университет информационных технологий, Алматы, Казахстан; ${ }^{2}$ Алматинский университет энергетики и связи, Алматы, Казахстан

\section{ДИНАМИКА СБЕРЕЖЕНИЙ НАСЕЛЕНИЯ В КАЗАХСТАНЕ}

Аннотация. В статье исследуется динамика сбережений населения, а также факторы, влияющие на них. Динамика сбережений населения измерялась сбережениями физических лиц. В качестве потенциальных факторов была принята средняя зарплата, обменный курс и процентная ставка как по депозитам в тенге, так и по депозитам в иностранной валюте. При выявленных значимых факторах была разработана соответствующая регрессионная модель. Было подтверждено соотношение между депозитами физических лиц и средней урезанной зарплатой, депозитами физических лиц и курсом валют. В целях сравнения изменений компонентов всех депозитов были применены структурный анализ и анализ динамики. Результаты показывают положительную динамику депозитов физических лиц в тенге, нежели в долларах США. Для целей исследования использовались статистические данные на 2010-2017 годы. Кроме того, изучался эффект внедрения Казахстанского фонда страхования вкладов на объем депозитов. Среди результатов исследования неожиданным было то, что процентная ставка по депозитам и объем депозитов не взаимосвязаны. Депозиты 
считаются одним из источников инвестиций в экономику. Поэтому были сделаны некоторые прогнозы по объему депозитов на ближайшие годы. Заключение обобщает основные результаты исследований.

Ключевые слова: сбережения населения, сбережения физических лиц, депозиты, страхование вкладов, Казахстанский фонд страхования вкладов

$$
\begin{gathered}
\text { Ш.Г. Джумадилова }{ }^{1}, \text { Б.ж. Атабай } \\
{ }^{1} \text { Халықаралық ақпараттық технологиялар университеті, Алматы, Қазақстан } \\
{ }^{2} \text { Алматы энергетика және байланыс университеті, Алматы, Қазақстан }
\end{gathered}
$$

\section{КАЗАҚСТАНДАҒЫ ХАЛЫҚТЫН ЖИНАҚТАРЫНЫН ДИНАМИКАСЫ}

Аннотация. Мақалада халықтың жинақтарының динамикасы, сондай-ақ оларға ықпал ететін факторлар қарастырылады. Халықтың жинақтау динамикасы жеке тұлғалардың жинақ ақшасымен өлшенді. Теңгедегі де, шетел валютасындағы да депозиттер бойынша ықтимал факторлары ретінде орташа жалақы, айырбас бағамы мен пайыздық мөлшерлеме қабылданды. Белгіленген маңызды факторлармен тиісті регрессиялық модель әзірленді. Жеке тұлғалардың депозиттері мен орташа айлық жалақының, жеке тұлғалардың депозиттері мен айырбас бағамдарының арасындағы арақатынас расталды. Барлық депозиттер құрамдас бөліктеріндегі өзгерістерді салыстыру үшін құрылымдық талдау және динамикалық талдау қолданылды. Нәтижелер АҚШ долларымен емес, теңгедегі жеке тұлғалардың салымдарының өсу динамикасын көрсетті. Зерттеу мақсатында 2010-2017 жылдарға арналған статистикалық деректер пайдаланылды. Бұдан басқа, қазақстандық депозиттерге кепілдік беру қорын енгізуінің депозиттердің көлеміне әсері зерттелді. Зерттеу нәтижелері бойынша депозиттер сыйақы мөлшерлемесі және депозиттердің көлемі өзара байланысты емес болып шықты. Депозиттер экономикадағы инвестиция көздерінің бірі болып саналады. Соған орай, жақын болашақта депозиттердің көлемі бойынша кейбір болжамдар жасалды. Зерттеудің негізгі нәтижелері қорытынды бөлімінде баяндалған.

Түйін сөздер: халықтың жинақ ақшасы, жеке тұлғалардың жинақтары, депозиттер, салымдарды сақтандыру, қазақстандық депозиттерге кепілдік беру қоры

Information about authors:

Jumadilova Sh.G. - International Information Technology University, Almaty, Kazakhstan

Assistant professor, PhD, E-mail: sh.jumadilova@iitu.kz, ORCID 0000-0001-8509-3688;

Atabay B.Zh. - Almaty University of Power Engineering and Communication, Almaty, Kazakhstan Senior lecturer, begeibek@gmail.com, ORCID 0000-0003-2891-7171 


\section{МАЗМҰНЫ}

Беспаева Р.С., Бугубаева Р.О., Мануэль Ф. Грела2. Көрсеткіштердің теңдестірілген жүйесі негізінде Щучинск-Бурабай курорттық аймағын дамытудың кешенді стратегиясын қалыптастыру ................................................................................ 5

Аюпова 3.К., Құсайынов Д.Ө.Азаматтық процесстерді жетілдірудегі интеграцияның кейбір қырлары...................... 13

Құсайынова А. А., Вальдемар Козловски, Геращенко И. П.Қазақстан республикасындағы міндетті әлеуметтік сақтандырудың қаржылық-құқықтық тетіктерінің ерекшеліктері.

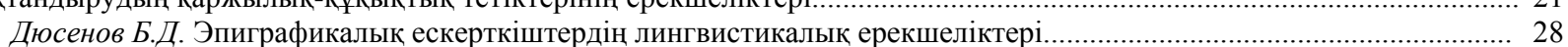

Джумадилова Ш.Г., Атабай Б.Ж. Қазақстандағы халықтың жинақтарының динамикасы......................................... 33

Карабалина А.А., Альситова А. Б., Кереймаганбетова Ж.Н., Абишева Н. М. Құндылық - рухани-адамгершілік

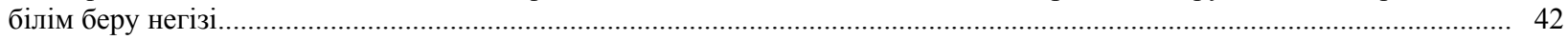

Кенжебаева Д.К., Өрмөрза Б. Ғ., Дашгин Махаммадли. Қазақстандық заманауи жастардың құндылығы............. 51

Нурманова А.Ш., Медерова Д.Е., Дюсенов Б.Д. «Бөкейхан әулетінің талдыбейіт қорымы» эпиграфикалық ескерткіштері тарихи дереккөз ретінде.

Кыдырова Ж.Ш., Онласынов Е.З., Абишова А.У., Шадиева А.А. Оңтүстік Қазақстан облысы сүт және сүт өнімдері нарығындағы жағдайды зерттеу ......

Абимова Г.У., Аманжолов Р., Мынбаева Б.Н., Ибрагимова Д.И. ЖОО-да биолог-студенттердің жобаларды

ұйымдастырылуы мен орындалуына даярлығы.......

Балтабаева А.Ю., Ризаходжаева Г. Мәдени интеграция үдерісіндегі жібек жолының феномені............................... 9

Бурганова Р.И., Абдугалина С.Е., Туякова А.Е. Студенттерге бағытталған білім беру арқылы білім сапасын

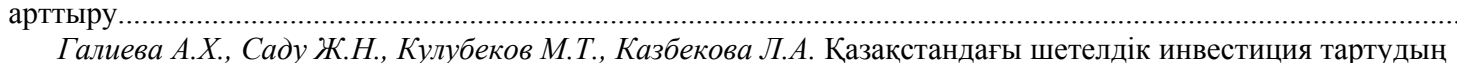

институционалдық жағдайын (талаптарын) бағалау..

Джалилов 3.Г., Батырхан Б.Ш. ХX ғ. екінші жартысындағы шетелдік исламтанушылардың ислам және саясат

туралы теориялық дискурсы.......

Джумабекова А.Т., Канатова А.Ж. Қаржылық ынтымақтастық жағдайларындағы Қазақстан республикасының

ұлттық банкінің өткізу механизмінің өзгеруі......

Дүйсен Г. М., Айтжанова Д. А. Қазақстан және Орталық Азия елдеріндегі көші-қон процесстері дамуының мәселелері мен ерекшеліктері

Есендұлова М.Н. Қазақстандағы « Қиын балаларды» оңалтудың және әлеуметтендірудің психологиялық ерекшеліктері

Жакишева К.М., Жуманова Д.Т., Мукашева Г.М. Экономиканың аграрлық секторының тұрақты дамуына арналған ауыл шаруашылық кәсіпорындарының қаржылық шарттарын мониторингінің рөлі.....

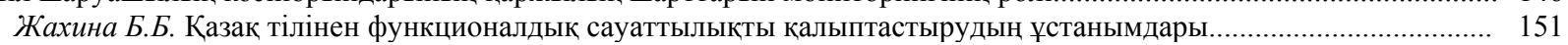

Идресова У.Х., Садуахасова 3.Ж., Муханова А.Т. Криминалистика....................................................................... 156

Савельева В. В. Қазақстандағы кредит технологиясын пайдалану және дамуының тарихи және педагогикалық базасы.

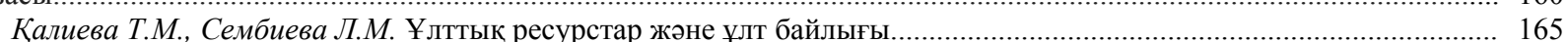

Каримова Р.У., Хаджиева Г.У. ҚХР Ұлттық саясаты контексіндегі ШҰАА-ның этносаяси және әлеуметтікэкономикалық трансформациясы мәселесі.

Керімбек Г., Молдашбаева Л., Джрауова Қ., Ажмухамедова А., Мизанова А. Қазақстан республикасының

республикалық бюджетіне түсетін салық түсімдерінің көрсеткіштерін талдау және бағалау.....

Жолдасбекова С.А., Парманкулова П.Ж., Асаналиев М.К. Мүмкіндігі шектеулі балаларды дамытудағы ұлттық ойындар

Молдакенова Е.К., Байгабулова К.К., Онаева Б.Т. БҚО-да инновациялық үрдістерді басқарудың аймақтық

аспектілігі жүйесінің дамудың жолдары.

Мұратова Г.К., Шаушенова А.Г., Жумасеитова С.Д., Онұварбаева М.Б.Білім беру үрдісінде бұлттық

технологияларын қолдану......

Несіпбеков E. Н., Аппакова Г.Н. Кәсіпорынның инвестициялық портфелін қалыптастырудың теориялық

Нургабылов М.Н., Барлыков Е.К., Егембердиева С.М. ҚР есеп өнеркәсібінің дамуының басқаруының трендсі....... 220

Нурымбетов Т.Я., Абишова А.У., Уразбаева Г.Ж., Кыдырова Ж.Ш., Байнеева П.Т., Абишо Н.У. Модернизациялық

жағдайындағы қр халқын әлеуметтік қолдауының басымдықтары.....

Рахимова С. А., Тургумбекова М. М. Қазақстан республикасындағы шағын және орта бизнестіңмемлекеттік қолдау

бағдарламалары және олардың тиімділігін жүзеге асыру шаралары.......................................................................... 233

Руденко Е.И. Орталық пен Оңтүстік Азия мемлекеттері арасындағы ұғынудың бұрмалануы - «Жұмсақ күш»

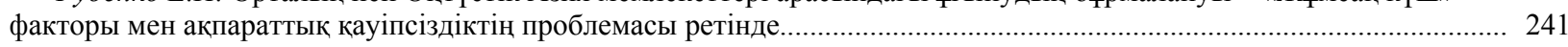

Тохтабаева Ш. Қазына-сандық.......................................................................................................... 251

Утепкалиева К.М., Сабирова Р.К., Кенбаева Г.У. Мұнай-газ секторындағы мемлекеттік-жеке серіктестікті дамыту

Мыңбаев Д. Е. Банкте басқару есебін ұйымдастыру тұжырымдамасы...

Султанова Г.С. Жаңа формацияның экономисі - бакалаврдың кәсіби құзыреттілігін қалыптастырудың

Шаяхметова А.А. Университет жағдайында инклюзивті білім беру үшін педагогтарды оқыту....... 


\section{СОДЕРЖАНИЕ}

Беспаева Р.С., Бугубаев Р.О., Мануэль Ф. Грела. Формирование комплексной стратегии развития ЩучинскоБоровской курортной зоны на основе сбалансированной системы показателей. Аюпова 3.К., Кусаинов Д.У., Уинстон Наган. Некоторые грани интеграции в совершенствовании гражданского процесса.

Кусаинова А.А., Козловски Вальдемар, Геращенко И.П. Обзор некоторых особенностей финансово-правового механизма обязательного социального страхования в республике Казахстан......

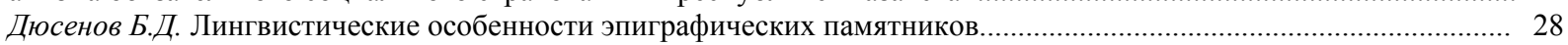

Джумадилова Ш.Г., Атабай Б.Ж.Динамика сбережений населения в Казахстане................................................... 33

Карабалина А.А., Альситова А. Б., Кереймаганбетова Ж.Н., Абишева Н. М. Ценность как базовая основа духовнонравственного образования.

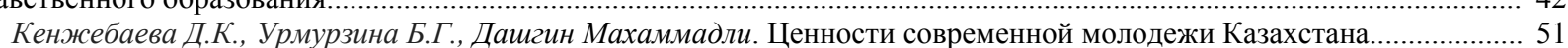

Нурманова А.Ш., Медерова Д.Е., Дюсенов Б.Д. Эпиграфические памятники «Некрополи талдыбейит династии

Бокейхановых» как исторический источник.

Кыдырова Ж.Ш., Онласынов Е.З., Абишова А.У., Шадиева А.А.Исследование ситуации на рынке молока и молочной продукции южно-казахстанской области

Абишова Г.У., Аманжолов Р., Мынбаева Б.Н., Ибрагимова Д.И. Готовность студентов-биологов к организации

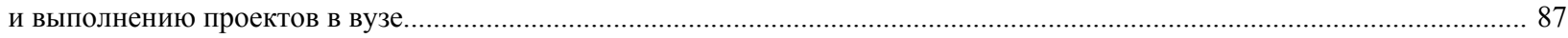

Балтабаева А.Ю., Ризаходжаева Г. Феномен великого шелкового пути в процессе культурной интеграции............... 91

Бурганова Р.И., Абдугалина С.Е., Туякова А.Е. Повышение качества образования посредством

студентоцентрированного обучения...

Галиева А.Х., Саду Ж.Н., Кулубеков М.Т., Казбекова Л.А. Оценка институциональных условий привлечения

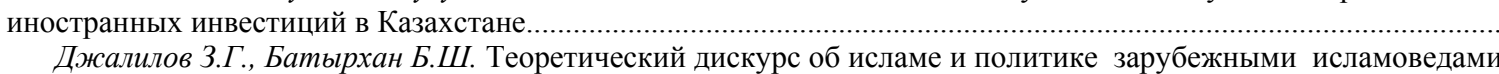
второй половины ХX в.

Джумабекова А.Т., Канатова А.Ж. Трансформация трансмиссионного механизма национального банка республики

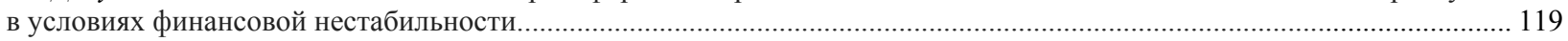

Дуйсен Г.М., Айтжанова Д.А. Проблемы и особенности развития миграционных процессов в Казахстане

и странах Центральной Азии.

Есенгулова М.Н. Психологические особенности реабилитации и социализации "Трудных подростков"

в Казахстане".

Жакишева К.М., Жуманова Д.Т., Мукашева Г.М.Роль мониторинга финансового состояния сельскохозяйственных

предприятий в обеспечении устойчивого развития аграрного сектора экономики.........................................................146

Жахина Б.Б. Принципы формирования функциональной грамотности казахского языка.......................................... 151

Идресова У.Х., Садуахасова 3.Ж., Муханова А.Т. Криминалистика......................................................................... 156

Савельева B.B. Исторические и педагогические основы формирования и разработки кредитной технологии

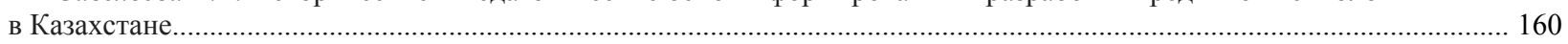

Калиева Т.М., Сембиева Л.М. Национальные ресурсы и богатство нации.................................................. 165

Каримова Р.У., Хаджиева Г.У. К вопросу об этно-политической и социально-экономической трансформации

СУАР в контексте национальной политики КНР

Керимбек Г., Молдашбаева Л., Джрауова Қ., Ажмухамедова А., Мизанова А. Анализ и оценка показателей

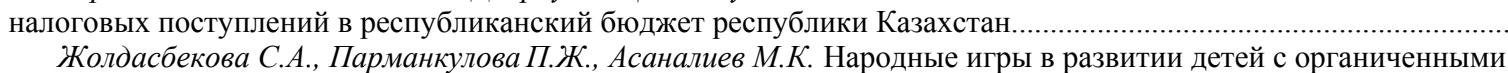

Жолдасбекова С.А., Парманкулова П.Ж., Асаналиев М.К. Народные игры в развитии детей с органиченными

Молдакенова Е.К., Байгабулова К.К., Онаева Б.Т.Пути развития системы регионального аспекта управления

инновационными процессами в АПК.

Муратова Г.К., Шаушенова А.Г., Жумасеитова С.Д., Онгарбаева М.Б. Применение облачных технологий

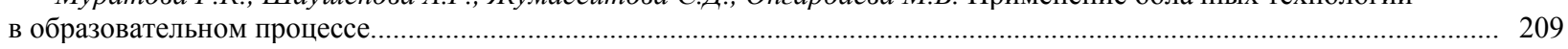

Несипбеков Е.Н., Аппакова Г.Н. Теоретические аспекты формирования инвестиционного портфеля предприятия. 214

Нургабылов М.Н., Барлыков Е.К., Егембердиева С.M. Тенденции управления развитием мясоперерабаты-

вающей отрасли в РК.

Нурымбетов Т.Я., Абишова А.У., Уразбаева Г.Ж., Кыдырова Ж.Ш., Байнеева П.Т., Абишов Н.У. Приоритеты

социальной поддержки населения РК в условиях модернизации................................................................................. 22

Рахимова С. А., Тургумбекова М. М. Программы государственной поддержки мсб в республике Казахстан и меры

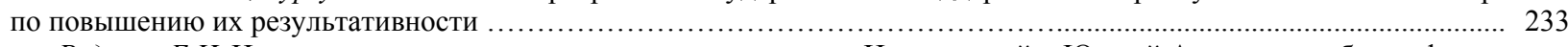

Руденко Е.И. Искаженность восприятия между государствами Центральной и Южной Азии как проблема фактора

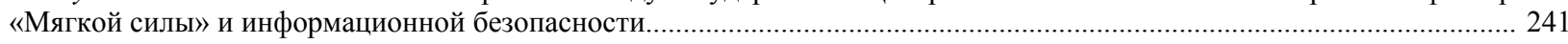

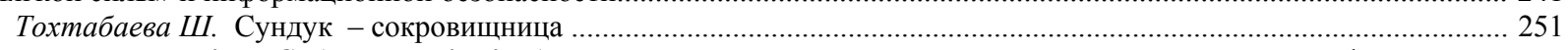

Утепкалиева К.М., Сабирова Р.К., Кенбаева Г.У.Развитие государственно-частного партнерства в нефтегазовой

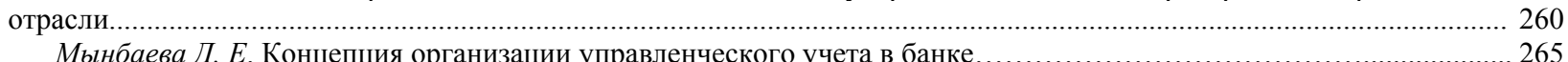

Мынбаева Д. Е. Концепция организации управленческого учета в банке...........................................2.
Султанова Г.С. Педагогические аспекты формирования профессиональных компетенций бакалавра - экономиста

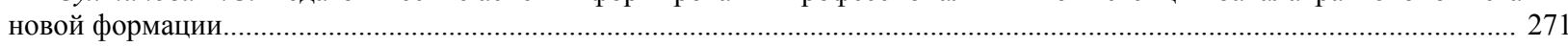

Шаяхметова А.А. О подготовке педагогических кадров к инклюзивному образованию в условиях вуза................ 277 


\section{CONTENTS}

Bespayeva R.S., Bugubayeva R.O., Manuel F. Grela. Formation of the complex strategy for development of the Schuchinsk-

Burabay resort area based on the balanced system of indicators.

Ayupova Z.K., Kussainov D.U., Winston Nagan. Some facets of integration in themodernization ofthe civil process..............13

Kussainova A.A., Kozlowski Waldemar, Gerashchenko I.P. The review of some features of the financial legal mechanism of obligatory social insurance in the republic of Kazakhstan...

Dyussenov B.D. Linguistic features of epigraphic monuments................................................................................ 28

Jumadilova Sh.G., Atabay B.Zh. Dynamics of the population savings in Kazakhstan.......................................................... 33

Karabalina A.A., Alsitova A.B., Kereimaganbetova Zh.N., Abisheva N.M. The values as critical factor of moral education... 42

Kenzhebayeva D.K., Urmurzina B.G., Dashqin Mahammadli. The modern youth values in Kazakhstan............................. 51

Nurmanova A.S., Mederova D.E., Dyussenov B.D. "Bokeykhanov dynasty taldybeyit necropolis" epigraphic monuments

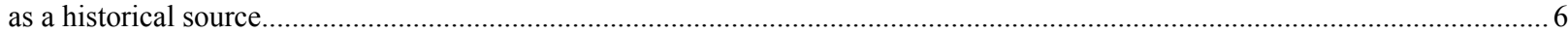

Kydyrova Zh.Sh., Onlasynov E.Z., Abishova A.U., Shadieva A.A.Research of the situation in the market of milk and dairy

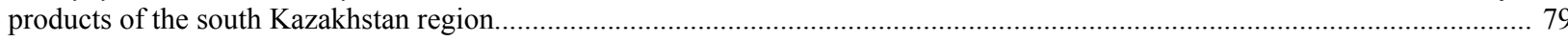

Abishova G.U., Amanzholov R.A., Mynbayeva B.N., Ibragimova D.I. Readiness of students-biologists for the organization

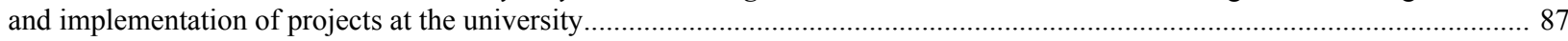

Baltabayeva A.Y., Rizakhojayeva $G$. The phenomenon of the great silk road in the cultural integration process................... 91

Burganova R.I., Abdugalina S.E., Tuyakova A.E. Improving the quality of education through student-centered education... 102

Galiyeva A.Kh., Sadu Zh.N., Kulubekov M.T., Kazbekova L.A. Assessment of the institutional terms of the foreign

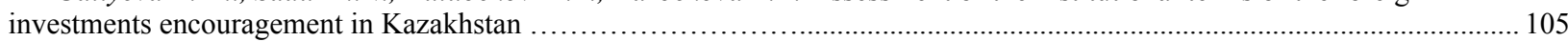

Dzhalilov Z.G. Theoretical discourse on islam and politics in foreign humanism of the second half of 20th century.......... 112

Dzhumabekova A.T., Kanatova A.ZH. Transformation of the transmission mechanism of the national bank of the republic

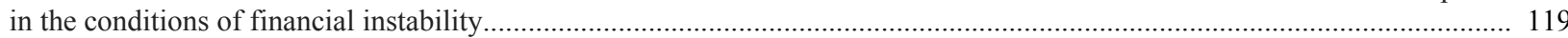

Suleimenov R.B. Problems and features of the development of migration processes in Kazakhstan and Central Asia.......... 124

Yesengulova M.N. Psychological aspects of reintegration and resocialization of "Trouble" adolescents in Kazakhstan....... 134

Zhakisheva K.M., Zhumanova D.T., Mukasheva G.M.The role of monitoring the financial condition of agricultural

enterprises in ensuring sustainable development of the agrarian sector of the economy......................................................... 146

Zhakhina B.B. Principles of functional literacy formation of the kazakh language....................................................... 151

Idresova U.Kh., Saduahasova Z.Zh., Mukhanova A.T. Criminalistics............................................................................. 156

Savelyeva $V . V$. Historicalandpedagogical bases of formation and development of credit technology in Kazakhstan........... 160

Kaliyeva T.M., Sembiyeva L.M. National Resources and national wealth.................................................................. 165

Karimova R., Hajiyeva G. Examining ethno-political and SOCIO-economic transformation of the xinjiang uyghur

autonomous region in the context of the PRC national policies........................................................................................ 176

Kerimbek G., Moldashbayeva L., Jrauova K., Azhmukhamedova A., Misanova A. Analysis and evaluation of reduction

of tax recovery of the republic of kazakhstan on the budget of the republic of Kazakhstan................................................. 185

Zholdasbekova S.A., Parmankulova P.Zh., Assanaliyev M.K. Folk games in the education of children with physical, mental and sensory disturbances..

Moldakenova E.K., Baygabulova K.K., Onaeva B.T. Ways of development of the system of the regional aspect of managing innovative processes in the APC.

Muratova G.K., Shaushenova A.G., Zhumassseitova C.D., Ongarbayeva M.B. Application of cloud technologies in the educational process......

Nurgabylov M.N., Barlikov E.K., Egemberdieva S.M. Trends of management of the development of meat processing industry in RK

Nurymbetov T.Ya., Abishova A.U., Urazbaeva G.Zh., Kydyrova Z.Sh., Baineeva P.T., Abishov N.U. Priorities of social support of the population of republic of Kazakhstan in the conditions of modernization........

Rakhimova S. A., Turgumbekova M. M. Programs of government support for sme in the republic of Kazakhstan and measures to enhance their efficiency.....

Rudenko Ye.I. Misperception between the states of Central and South Asia as a 'Soft power' and information security issue...

Tokhtabayeva Sh. Zh. Treasure-chest.

Utepkalieva K.M., Sabirova R.K., Kenbaeva G.U.Development of public private partnership approach in oil and gas

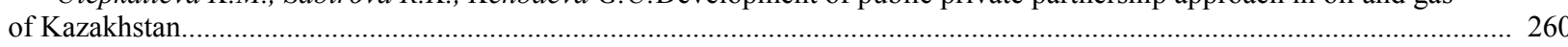

Mynbayeva D.E. Concept of organization of management accounting in bank ........................................................... 265

Sultanova G. S. Pedagogical aspects of formation of professional competence of the bachelor-economist of the new formation

Shayakhmetova A.A. On the training of teaching staff for inclusive education under the conditions of higher education institution. 


\section{PUBLICATION ETHICS AND PUBLICATION MALPRACTICE IN THE JOURNALS OF THE NATIONAL ACADEMY OF SCIENCES OF THE REPUBLIC OF KAZAKHSTAN}

For information on Ethics in publishing and Ethical guidelines for journal publication see http://www.elsevier.com/publishingethics and http://www.elsevier.com/journal-authors/ethics.

Submission of an article to the National Academy of Sciences of the Republic of Kazakhstan implies that the work described has not been published previously (except in the form of an abstract or as part of a published lecture or academic thesis or as an electronic preprint, see $\mathrm{http} / / / \mathrm{www} . e l s e v i e r . c o m / p o s t i n g p o l i c y)$, that it is not under consideration for publication elsewhere, that its publication is approved by all authors and tacitly or explicitly by the responsible authorities where the work was carried out, and that, if accepted, it will not be published elsewhere in the same form, in English or in any other language, including electronically without the written consent of the copyrightholder. In particular, translations into English of papers already published in another language are not accepted.

No other forms of scientific misconduct are allowed, such as plagiarism, falsification, fraudulent data, incorrect interpretation of other works, incorrect citations, etc. The National Academy of Sciences of the Republic of Kazakhstan follows the Code of Conduct of the Committee on Publication Ethics (COPE), and follows the COPE Flowcharts for Resolving Cases of Suspected Misconduct (http://publicationethics.org/files/u2/New_Code.pdf). To verify originality, your article may be checked by the originality detection service Cross Check http://www.elsevier.com/editors/plagdetect.

The authors are obliged to participate in peer review process and be ready to provide corrections, clarifications, retractions and apologies when needed. All authors of a paper should have significantly contributed to the research.

The reviewers should provide objective judgments and should point out relevant published works which are not yet cited. Reviewed articles should be treated confidentially. The reviewers will be chosen in such a way that there is no conflict of interests with respect to the research, the authors and/or the research funders.

The editors have complete responsibility and authority to reject or accept a paper, and they will only accept a paper when reasonably certain. They will preserve anonymity of reviewers and promote publication of corrections, clarifications, retractions and apologies when needed. The acceptance of a paper automatically implies the copyright transfer to the National Academy of sciences of the Republic of Kazakhstan.

The Editorial Board of the National Academy of sciences of the Republic of Kazakhstan will monitor and safeguard publishing ethics. 
Правила оформления статьи для публикации в журнале смотреть на сайте:

\section{www:nauka-nanrk.kz}

\section{social-human.kz}

Редакторы М.С. Ахметова, Т.А. Апендиев, Д.С. Аленов

Верстка на компьютере А.М. Кульгинбаевой

Подписано в печать 08.12.2018

Формат 60x881/8. Бумага офсетная. Печать - ризограф.

17,7 п.л. Тираж 500. Заказ 6.

Национальная академия наук $Р К$

050010, Алматы, ул. Шевченко, 28, т. 272-13-18, 272-13-19 